\title{
Analisis Strategi Kreatif Iklan Yellow Fit di Media Sosial Instagram dalam Melakukan Positioning Sebagai “\#1 Diet \& Healthy Catering”
}

\author{
Keshena Sutiady $^{1}$, Diah Ayu Candraningrum ${ }^{2 *}$ \\ ${ }^{1}$ Fakultas Ilmu Komunikasi Universitas Tarumanagara, Jakarta \\ Email: keshena.915170074@stu.untar.ac.id \\ ${ }^{2}$ Fakultas Ilmu Komunikasi Universitas Tarumanagara, Jakarta* \\ Email: diahc@fikom.untar.ac.id
}

Masuk tanggal : 15-12-2021, revisi tanggal : 06-01-2022, diterima untuk diterbitkan tanggal : 16-01-2022

\begin{abstract}
Digitalization has changed many aspects in the business world, one of which is the world of advertising. This change makes every business actor must be able to adapt to the progress of the times so as not to be forgotten by society. Same thing with the world of advertising which has to be more creative every day. One business that applies a creative strategy is Yellow Fit. This study aims to determine the creative advertising strategy carried out by the diet food catering company Yellow Fit. The main theory used is the theory of creative advertising strategy, marketing communication, and brand positioning. The research method used is a qualitative method with a descriptive case study approach. Data collection was carried out by in-depth interviews, literature study, and observation. The results of this study indicate that Yellow Fit uses generic creative strategies and brand positioning in doing digital marketing on their Instagram social media.
\end{abstract}

Keywords: brand positioning, creative strategy, Instagram, social media

\begin{abstract}
Abstrak
Digitalisasi telah mengubah banyak aspek dalam dunia bisnis, salah satunya adalah dunia periklanan. Perubahan ini membuat setiap pelaku usaha harus mampu beradaptasi dengan kemajuan zaman agar tidak dilupakan oleh masyarakat. Sama hal nya dengan dunia periklanan yang harus menjadi lebih kreatif setiap hari. Salah satu bisnis yang menerapkan strategi kreatif adalah Yellow Fit. Penelitian ini bertujuan untuk mengetahui strategi kreatif periklanan yang dilakukan oleh perusahaan katering makanan diet Yellow Fit. Teori utama yang digunakan adalah teori strategi kreatif periklanan, komunikasi pemasaran, dan brand positioning. Penelitian ini menggunakan pendekatan penelitian kualitatif dengan metode studi kasus yang bersifat deskriptif. Pengumpulan data dilakukan dengan wawancara mendalam, studi kepustakaan, dan observasi. Hasil dari penelitian ini menunjukkan bahwa Yellow Fit menggunakan strategi kreatif generik yaitu strategi yang menggunakan keunggulan cost atau harga produk dan brand positioning dalam melakukan pemasaran digital di media sosial instagram mereka.
\end{abstract}

Kata Kunci: brand positioning, Instagram, media sosial, strategi kreatif

\section{Pendahuluan}

Kemajuan zaman ini pada akhirnya menuntut setiap perusahaan mampu bersaing secara kreatif dalam menghasilkan bentuk-bentuk promosi bagi perusahaan mereka. Dengan fakta mengenai masyarakat Indonesia yang gemar menghabiskan waktu mereka di dunia internet, maka perusahaan pun perlu menyesuaikan promosi mereka sesuai dengan kebiasaan masyarakat saat ini. Salah satu tujuan setiap 
perusahaan ialah untuk membentuk sebuah positioning dalam benak konsumen. Namun dalam mewujudkan pemosisian tersebut, ada banyak yang harus dilakukan, salah satu nya adalah membentuk sebuah iklan kreatif.

Nurfebiaraning (2016) mengatakan bahwa proses untuk menghasilkan iklan yang efektif diperlukan strategi yang kreatif, eksekusi pesan iklan yang tepat sesuai dengan tujuan, target audiens, serta pemilihan media iklan. Menjamurnya media iklan saat ini membuat pengiklan perlu jeli dan teliti dalam memilih media iklan mereka. Salah satu media baru yang banyak dipilih oleh pengiklan ialah media sosial instagram.

Menurut Kotler dan Keller dalam Kusuma \& Sugandi (2019), komunikasi pemasaran adalah suatu kegiatan yang bertujuan untuk memberi informasi, mempersuasi, dan mengingatkan konsumen akan produk yang dijual oleh sebuah perusahaan. Sedangkan menurut Kennedy dan Soemanagara dalam Kusniadji (2017) mengatakan bahwa komunikasi pemasaran atau marketing communication adalah sebuah kegiatan pemasaran yang melibatkan teknik-teknik komunikasi dan berfungsi untuk mencapai tujuan perusahaan.

Bentuk iklan dari hari ke hari harus semakin menarik dan unik agar mampu menarik minat masyarakat. Dengan demikian perlu adanya strategi kreatif yang menjadi landasan dalam pembentukan sebuah iklan. Dalam teori strategi kreatif iklan ada tujuh jenis pendekatan strategi yang dapat digunakan sebuah perusahaan dalam membuat iklan kreatif.

Sebagai perusahaan katering makanan diet, Yellow Fit perlu berpikir keras untuk melakukan pemasaran secara digital yang efektif bagi masyarakat. Pandangan masyarakat akan sulit nya diet menjadi sebuah tantangan tersendiri bagi pebisnis makanan diet untuk tetap mampu menjual produk mereka. Selain kepentingan sales, sebuah perusahaan juga ingin membuat pemosisian merek di benak konsumen, Yellow Fit ingin menjadi nomor satu dalam bidang katering makanan diet.

Yellow Fit telah berdiri sejak tahun 2017 dan giat melakukan pemasaran digital melalui media sosial instagram. Hingga 11 Desember 2020, Yellow Fit memiliki followers instagram sebanyak 244.900 akun.

Berdasarkan penjelasan di atas, maka rumusan masalah dalam penelitian ini adalah "Bagaimana strategi kreatif iklan yang dilakukan oleh Yellow Fit dalam melakukan positioning sebagai \#1 Diet \& Healthy Catering?"

\section{Metode Penelitian}

Pendekatan penelitian yang penulis gunakan dalam penelitian ini adalah pendekatan kualitatif deskriptif. Menurut Mantra dalam Siyoto \& Sodik (2015), yang dimaksud dengan pendekatan kualitatif adalah prosedur penelitian yang memiliki output berupa data deskriptif yang disusun baik melalui lisan atau tulisan dari objek penelitian yang diamati.

Metode penelitian yang dipilih oleh penulis adalah metode penelitian studi kasus. Patton mengungkapkan bahwa studi kasus adalah studi mengenai sebuah kompleksitas akan suatu kasus sehingga peneliti bertujuan untuk memahami kerumitan kasus tersebut (Raco, 2010). Sedangkan Creswell dalam Susila (2015) menambahkan studi kasus adalah sebuah kegiatan eksplorasi isu melalui berbagai macam kasus yang telibat di dalam nya dan merupakan hal yang relevan.

Teknik pengumpulan data dalam penelitian ini dilakukan melalui wawancara mendalam, observasi, dan studi kepustakaan. Menurut Bungin dalam Ricko \& Junaidi 
(2019), wawancara adalah kegiatan yang dilakukan dengan tujuan memperoleh data atau keterangan yang bermanfaat bagi kepentingan penelitian. Dalam penelitian ini, penulis melakukan wawancara dengan Darrell Lee sebagai penanggung jawab divisi digital marketing di YellowFit, Adythia Pratama sebagai ahli digital marketing, dan Juvanni Liusady serta Mirabela sebagai followers akun instagram @yellowfitkitchen.

Teknik analisis data yang digunakan adalah teknik analisis data kualitatif Miles dan Huberman. Miles dan Huberman dalam Cecariyani \& Sukendro (2018) menyebutkan bahwa ada tiga teknik analisis data dalam penelitian kualitatif, yaitu reduksi data, penyajian data, dan kesimpulan atau verifikasi. Sedangkan untuk teknik keabsahan data, penulis menggunakan teknik triangulasi sumber data. Dalam penelitian ini, penulis akan membandingkan data yang didapatkan dengan sumber lain sehingga mendapatkan banyak pandangan dari banyak sisi.

\section{Hasil Temuan dan Diskusi}

\section{Strategi Kreatif}

Dalam penelitian ini, penulis menemukan beberapa strategi yang digunakan oleh Yellow Fit dalam mewujudkan positioning sebagai \#1 Diet \& Healthy Catering. Dalam pembuatan konten di media sosial instagram, Yellow Fit mengutamakan caption dan visualisasi yang sangat baik karena menganggap bahwa saat ini masyarakat lebih tertarik dengan perusahaan yang mampu menyuguhkan gambar menarik. Selain itu, Yellow Fit juga menggunakan bahasa iklan yang sesuai pangsa pasar mereka, yaitu anak muda.

Dalam menyampaikan pesan iklan kreatif, Yellow Fit menggunakan dua pendekatan, yakni pendekatan strategi brand positioning dan pendekatan strategi generik. Ada beberapa tahapan yang dilalui oleh Yellow Fit dalam merancang sebuah strategi kreatif, diantaranya adalah sebagai berikut :

1. Perumusan Masalah, merupakan kegiatan menyelami masalah secara langsung untuk mengumpulkan data dan informasi yang diperlukan

2. Mengolah Informasi, merupakan kegiatan pengolahan data yang telah dikumpulkan dan melihat dari berbagai perspektif

3. Break, merupakan kegiatan menarik diri sebagai bentuk upaya merangsang ide kreatif yang muncul di waktu yang tidak dapat direncanakan sebelumnya

4. Verifikasi, merupakan kegiatan evaluasi untuk menilai apakah ide tersebut dirasa mampu menyelesaikan masalah yang dihadapi atau tidak

Yellow Fit kerap kali membuat iklan-iklan yang mengundang interaksi dengan followers mereka yang membuat Yellow Fit dikenal sebagai brand yang gaul. Kemudian Yellow Fit juga melakukan beberapa teknik pemasaran, yang pertama adalah program gratis ongkir yang diberlakukan karena Yellow Fit telah melakukan riset sebelumnya yang menunjukkan bahwa gratis ongkir meningkatkan penjualan.

Kedua, kejujuran adalah nomor satu bagi Yellow Fit karena tidak pernah membeli followers. Yellow Fit menganggap bahwa pembelian followers palsu akan menyulitkan mereka sendiri. Ketiga adalah pemberian jaminan uang kembali $100 \%$ untuk konsumen yang merasa ditipu oleh Yellow Fit karena tidak berhasil menurunkan berat badan atau konsumen yang tidak puas karena rasa makanan yang tidak enak. Hal ini dilakukan oleh Yellow Fit untuk memberikan fasilitas bagi konsumen sehingga konsumen merasa dipedulikan oleh perusahaan. Keempat, adalah bentuk kerja sama Yellow Fit dengan brand besar. 


\section{Brand Positioning}

Menurut Kellog dalam William (2015), brand positioning merujuk pada sebuah makna yang spesifik dalam benak konsumen. Positioning yang ingin dicapai oleh Yellow Fit adalah positioning sebagai katering diet nomor satu di antara para pesaing. Guna mencapai posisi tersebut di benak masyarakat, maka Yellow Fit berusaha keras untuk memenuhi empat elemen seperti yang dikemukakan oleh Clifton sebelum nya, yaitu:

1. Relevansi, Yellow Fit ingin membangun sebuah relevansi baik secara nilai fungsional ataupun emosional kepada para konsumen nya. Berkenaan dengan relevansi emosional, Yellow Fit ingin membentuk sebuah kebiasaan yang muncul dari dalam hati konsumen itu sendiri ketika memilih sebuah katering diet.

2. Kredibilitas, Yellow Fit selalu menjaga kredibilitas yang mereka bangun sejak awal berdirinya perusahaan ini. Sesuai dengan pemosisian merek yang mereka bangun, Yellow Fit berupaya untuk menyesuaikan agar posisi merek yang mereka tuju sinkron dengan kredibilitas mereka di mata publik. Salah satu bentuk nyata yang dilakukan oleh Yellow Fit adalah penggunaan dokter gizi dalam merancang menu-menu makanan diet yang mereka sediakan. Hal ini dilakukan Yellow Fit dengan tujuan membentuk sebuah perusahaan diet yang benar-benar memiliki kalkulasi secara tepat di setiap makanan yang mereka sajikan

3. Diferensiasi, Yellow Fit masih berusaha untuk membentuk sebuah perbedaan signifikan antara perusahaan mereka dengan perusahaan kompetitor. Perbedaan ini lah yang nantinya menjadi alasan mengapa seseorang perlu memilih Yellow Fit dibandingkan dengan merek lain.

4. Stretch, Yellow Fit terus melakukan analisis pasar untuk mengetahui apa yang menjadi wants dari masyarakat pada saat itu. Selain analisis pasar, Yellow Fit juga melakukan analisis kompetitor untuk mengetahui kelemahan perusahaan mereka dibandingkan dengan perusahaan lain, dan setelahnya melakukan perbaikan mutu dan kualitas masakan mereka sendiri agar mampu bersaing dengan kompetitor yang menjadi market leader pada saat itu.

\section{Jenis Iklan}

Adapun beberapa jenis iklan yang dihasilkan oleh Yellow Fit adalah sebagai berikut:

1. Iklan Informatif, iklan jenis ini bertujuan untuk menginformasikan segala bentuk informasi terkait dengan produk yang diiklankan. Adanya iklan ini berguna untuk memberikan informasi kepada masyarakat mengenai produk yang tersedia di Yellow Fit.

2. Iklan Persuasif, iklan jenis ini bertujuan untuk menarik minat beli konsumen akan produk yang diiklankan. Iklan persuasif dibentuk dengan memberikan visual yang menggugah dan deskripsi foto yang menarik. Bertujuan untuk memberi anjuran masyarakat agar membeli produk yang diiklankan serta memilih produk yang diiklankan dibandingkan dengan produk kompetitor.

3. Iklan Penambah Nilai, iklan jenis ini bertujuan untuk menambah value perusahaan tersebut di mata masyarakat. Iklan-iklan yang dihasilkan dibentuk sedemikian rupa untuk mengangkat nilai perusahaan itu sendiri. 


\section{Simpulan}

Berdasarkan hasil analisa strategi kreatif yang dilakukan oleh Yellow Fit, peneliti menyimpulkan bahwa strategi kreatif iklan perlu dilakukan oleh setiap perusahaan untuk mendapatkan hasil yang lebih daripada yang menjadi tujuan di awal. Kemudian dalam merancang strategi kreatif tersebut, ada proses kreatif yang perlu dilalui sebelumnya, yaitu proses terjun ke dalam permasalahan, mengolah informasi, menganalisis dari berbagai sisi, hingga melakukan evaluasi atas ide yang telah didapatkan.

Strategi kreatif yang dipilih oleh Yellow Fit adalah strategi generik dan strategi brand positioning. Yellow Fit ingin dikenal oleh masyarakat sebagai katering makanan diet nomor satu di antara seluruh kompetitor yang ada, selain itu Yellow Fit juga berusaha untuk menciptakan menu diet dengan harga yang affordable dan merupakan harga yang murah bagi banyak kalangan sehingga diet sehat tidak lagi menjadi gaya hidup yang mahal.

Kemudian Yellow Fit berupaya keras dalam mewujudkan pemosisian merek sebagai nomor satu dalam bidang katering diet dengan berbagai cara seperti penggunaan dokter gizi sebagai pendukung kredibilitas perusahaan, kolaborasi dengan brand besar, harga yang terjangkau, pengiriman bebas biaya, dan lain sebagainya sebagai bentuk diferensiasi Yellow Fit dengan perusahaan lain. Dengan demikian, Yellow Fit berharap nantinya mampu memosisikan merek mereka sebagai \#1 Diet \& Healthy Catering di benak konsumen.

Penulis berharap penelitian ini mampu memberikan sumbangsih baik secara akademis maupun praktis terhadap pihak-pihak terkait. Seperti peneliti yang akan meneliti hal serupa diharapkan mampu mengembangkan teori strategi kreatif iklan secara lebih luas dan juga bagi perusahaan mampu menerapkan pendekatanpendekatan strategi kreatif iklan dalam membuat sebuah iklan yang kreatif.

\section{Ucapan Terima Kasih}

Peneliti ingin mengucapkan terima kasih kepada Fakultas Ilmu Komunikasi Universitas Tarumanagara, narasumber, serta semua pihak yang turut membantu peneliti sehingga penelitian ini dapat diselesaikan.

\section{Daftar Pustaka}

Cecariyani, S. A., \& Sukendro, G. G. (2018). Analisis Strategi Kreatif dan Tujuan Konten Youtube (Studi Kasus Konten prank Yudist Ardhana). Prologia, 2(2), 495. https://doi.org/10.24912/pr.v2i2.3735

Kusuma, D. F., \& Sugandi, M. S. (2019). Strategi Pemanfaatan Instagram Sebagai Media Komunikasi Pemasaran Digital Yang Dilakukan Oleh Dino Donuts. Jurnal Manajemen Komunikasi, 3(1), 18. https://doi.org/10.24198/jmk.v3i1.12963

Nurfebiaraning, S. (2016). Strategi Kreatif Pesan Video Advertising "OREO Penuh Keajaiban” pada YouTube. 4(1). https://doi.org/10.12928/channel.v4i1.4205

Raco, J. (2010). Metode Penelitian Kualitatif: Jenis, Karakteristik, dan Keunggulannya. https://doi.org/10.31219/osf.io/mfzuj

Ricko, R., \& Junaidi, A. (2019). Analisis Strategi Konten Dalam Meraih Engagement pada Media Sosial Youtube (Studi Kasus Froyonion). Prologia, 3(1), 231. https://doi.org/10.24912/pr.v3i1.6245 
Siyoto, S., \& Sodik, M. A. (2015). Dasar metodologi penelitian. https://books.google.co.id/books?id=QPhFDwAAQBAJ\&printsec=frontcover\&

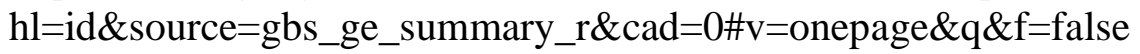

Susila, I. (2015). Pendekatan kualitatif untuk riset pemasaran dan pengukuran kinerja bisnis. http://journals.ums.ac.id/index.php/benefit/article/view/1413

William, W. (2015). Analisis strategi destination branding the breeze BSD city dalam membentuk brand positioning sebagai "The ultimate outdoor lifestyle excitement" (Periode 2014). 